\title{
ДО ПРОБЛЕМИ ВИХОВАННЯ І ФОРМУВАННЯ ОСОБИ МАЙБУТНЬОГО ФАХІВЦЯ НА КАФЕДРІ ХІРУРГІЧНОЇ СТОМАТОЛОГІї ОНМУ
}

\author{
А. Г. Гулюк, В. В. Парасочкіна \\ Одеський національний медичний університет
}

\section{PROBLEM OF EDUCATION AND FORMATION OF THE PERSON OF THE FUTURE EXPERT ON FACULTY SURGICAL ODONTOLOGY ONMU}

\author{
A. H. Huliuk, V. V. Parasochkina \\ Odessa National Medical University
}

\begin{abstract}
Стаття присвячена проблемі підвищення якості освіти на кафедрі хірургічної стоматології ОНМУ. Рішення цісї задачі полягає не тільки в навчанні студентів практичних навиків роботи лікаря-стоматолога-хірурга, але також вихованні грамотної, дисциплінованої, відповідальної особи. Способи і засоби досягнення цієї мети представлені в статті.
\end{abstract}

The article adduces the problem of education quality increase at the department of Surgical Odontology of ONMU. The decision of this task consists not only in training of students of practical skills of work of the doctor-dentist-surgeon, but also education of competent, disciplined, responsible person. The ways and means of achievement of this purpose are presented in the article.

Вступ. Проблема підготовки грамотних, висококваліфікованих фахівців є основним завданням професорсько-викладацького складу кафедри. Важливим пунктом досягнення цієї мети є не тільки навчання професійних навиків, але і виховна робота із студентами.

Основна частина. На практичних заняттях навчальна дисципліна зобов' язує студентів систематично і глибоко оволодівати теоретичними знаннями, практичними навиками і сучасними методами досліджень, набувати навиків організації лікувального процесу, дотримувати норми етики і деонтології в спілкуванні з пацієнтом, виконувати правила внутрішнього розпорядку лікувального закладу взагалі.

Майбутній лікар не тільки зобов'язаний пунктуально виконувати свої професійні обов'язки, але і володіти високою культурою праці. Сьогодні вже не достатньо простої старанності. Все більш зростає значення таких ділових якостей, як компетентність $\mathrm{i}$ ініціативність, готовність брати відповідальність на себе, уміння доводити до кінця почату справу.

Сучасний лікарповинен постійно примножувати свої знання за рахунок самоосвіти, читання спеціальної літератури, відвідин лекцій, семінарів, беручи участь у роботі конференцій, майстер-класів. В той же час, на етапі навчання в стінах вищого навчального зак- ладу якою б високоорганізованою і дисциплінованою не була людина, іiі самоосвіта повинна проходити під керівництвом кваліфікованих педагогів. Тому на кафедрі хірургічної стоматології ОНМУ велика увага приділяється такій формі навчання, як самостійна робота студента.

Необхідність спілкування студента 3 викладачем вирішує питання зразка для формування особистості майбутнього лікаря, тому що викладач $є$ сформованою особистістю, яка має повагу у своїх колег та у хворих.

У процесі навчання викладач формує у студентів такі орієнтаційні і мотиваційні установки, які визначають відповідальне ставлення кожного до своїх обов'язків. В той же час кожен студент до вступу до вищого навчального закладу певною мірою вже сформувався як особистість і є стійкою структурою, що включає мотиваційні, пізнавальні, емоційні, вольові компоненти. Незважаючи на те, що педагог працює з дорослою особою, він зобов'язаний сформувати у студента позитивне ставлення до своїх обов'язків, відчуття особистої відповідальності за свою поведінку, уміння управляти собою, зберігати самоконтроль у важких ситуаціях, навики дотримання встановленого порядку, взаємодії з товаришами по колективу, уміння проводити самооцінку поведінки 3 погляду

(C) А. Г. Гулюк, В. В. Парасочкіна 
ступеня ії відповідності вимогам суспільства і принципам моральності, уміння мобілізувати свої сили і здібності відповідно до вирішуваного завдання.

В ході проведення виховної роботи викладач орієнтується на такі критеріі, як строге дотримання студентами встановленого порядку і дисципліни, точне і ініціативне виконання своїх обов'язків, пунктуальне дотримання порядку денного, охайність зовнішнього вигляду, знання встановлених норм і правил, уміння управляти собою в складних клінічних ситуаціях, набуття навиків дисциплінованоїповедінки, самодисципліни.

Необхідно відзначити, що характер поведінки людини є наслідком злиття різноманітних чинників, особистого прикладу тих, що оточують, стилю спілкування і так далі. Зниження ефективності навчання залежить від багатьох чинників. Серед них можна виділити особисті якості студента (негативні риси характеру, шкідливі звички, недотримання норм етики тощо); недоліки і упущення у виховній роботі ( у їі змісті і формах, слабкій інформативності деяких заходів, недообліку запитів студентів та ін.); зниження вимогливості і ослаблення контролю з боку викладача; несприятлива психологічна атмосфера в самому студентському колективі. Усуненню вказаних чинників приділяється особлива увага на нашій кафедрі.

У студентському колективі дисциплінованість тим вище і стійкіше, ніж більш послідовно, психологічно і педагогічно обгрунтовано ведеться робота щодо зміцнення порядку і дисципліни на кафедрі.

Разом з тим дисципліна як зовнішній регулятор поведінки людини впливає наїі мислення, відчуття, волю, сприяючи тим самим виробленню необхідних навиків поведінки в соціумі. 3 точки зору і моральності і державної політики дотримання дисципліни є обов'язковою умовою нормального і стійкого функціонування

\section{Література}

1. Грішнова О. А. Людський капітал (формування в системі освіти і професійної підготовки) / О. А. Грішнова. -К. : Знання, КОО, 2001.

2. Кипень В. Викладачі вузів : соціологічний портрет / всіх ланок кафедри, а дисциплінованість студентів основа, на якій будуються якості особи майбутніх фахівців.

Психологічні передумови дисциплінованості-спрямованість особи студента, його темперамент, здібності, мотивація поведінки, рівень інтелектуальної і суспільної активності.

Негативно на процесі навчання позначається переоцінка студентами своїх знань і умінь, некритичне ставлення до своєї поведінки. Тільки на основі позитивної мотивації, засвоєних норм дисципліни чоловік підпорядковує свою поведінку їх вимогам.

Велике значення має робота над собою - самопізнання, самооцінка, самовиховання, аналіз своїх установок і відношення до дійсності.

Проте багато студентів не надають самодисципліні того значення, якого вона заслуговує. Підвищення дисциплінованості студентів в ході навчального процесу припускає узгодженість спільної виховної і організаторської роботи всіх співробітників кафедри на чолі із завідувачем.

Викладачеві необхідно враховувати, що поведінка студента обумовлена створенням ним ідеального образу дій, безпосередньою метою і мотивом. Бажання, прагнення, а також ідеали, погляди, інтереси - все це внутрішні стимули активності, що виявляється в діях і вчинках. Закріплення позитивної мотивації відповідно до вимог дисципліни - основа успішної педагогічної роботи кафедри.

Висновок. Облік педагогом суспільно значущих мотивів у поведінці студентів, морально-психологічна підготовка їх навчально-професійної діяльності, безумовне дотримання дисципліни - чинники, без яких неможлива успішна підготовка кваліфікованих фахівців-лікарів.

В. Кипень, Р. Коржів. - Донецьк, 2001.

3. Педагогічна майстерність / за ред. І. А. Зазюна. - К. : Вищашк., 1997. 